\title{
Opposition to the Proposal to Replace the Family Name Enterobacteriaceae ${ }^{\dagger}$
}

\author{
DON J. BRENNER
}

\author{
Molecular Biology Laboratory, Division of Bacterial Diseases, Centers for Infectious Diseases, Centers for \\ Disease Control, Atlanta, Georgia 30333
}

\begin{abstract}
The Subcommittee on the Taxonomy of Enterobacteriaceae unanimously recommends that the proposal to replace the family name Enterobacteriaceae with Escherichiaceae be rejected by the Judicial Commission. The arguments in support of this recommendation are as follows: (i) Enterobacteriaceae is a legitimate name that has been specifically conserved as an exception to Rule 9 of the International Code of Nomenclature of Bacteria; (ii) the continued use of this name satisfies Principle 1 of the Bacteriological Code (to "aim at stability of names; avoid or reject the use of names which may cause error or confusion; and avoid the useless creation of names"'); and (iii) Enterobacteriaceae is also specifically in accord with General Consideration 6, Principles 1, 8, and 9, Rules 21b, 23a, and 56b, and Opinion 15 of the Bacteriological Code, whereas the proposal to use Escherichiaceae violates each of these portions of the Bacteriological Code.
\end{abstract}

Goodfellow and Trüper proposed the name Escherichiaceae to replace the family name $E n$ terobacteriaceae (7). These authors argued that "Enterobacteriaceae is not formed in accord with the rules of bacteriological nomenclature," that "Enterobacteriaceae is the only exception to the rule stating how family names should be formed," and that this exception is maintained for "merely historical reasons." In this report, the Subcommittee on the Taxonomy of Enterobacteriaceae (Enterobacteriaceae Subcommittee) goes on record against the proposal of what is, in our opinion, the illegitimate name Escherichiaceae and recommends the continued use of the legitimate and conserved name Enterobacteriaceae.

In June 1979, a similar proposal-to change the family name Enterobacteriaceae to "Enterobacteraceae" - was made by Lapage (10). The Judicial Commission denied this request (14). Detailed opposition to the Lapage proposal was published $(5,6)$, and much of the rebuttal to the Lapage proposal applies equally well to the proposal of Goodfellow and Trüper to change the family name. The most pertinent points are summarized below, but readers are invited to refer to a paper by Farmer et al. for a full discussion of the objections to changing the name Enterobacteriaceae (5).

+ Submitted for the Subcommittee on the Taxonomy of Enterobacteriaceae and based on discussions held at the International Congress of Microbiology, August 1982, Boston, Mass., and material circulated to each member of the Subcommittee.
A brief historical look at the name Enterobacteriaceae should be helpful. The family name Enterobacteriaceae was proposed by Rahn in 1937 (13). This family had one genus, Enterobacter, which included species that had previously been in the genera "Aerobacter," "Eberthella,"' Erwinia, Escherichia, Klebsiella, Proteus, Salmonella, Serratia, and Shigella, as well as strains of Achromobacter, Flavobacterium, and Pseudomonas. A description was not given for the family or for the genus, and a type strain was not designated $(4,13)$. When the first International Bacteriological Code of Nomenclature was adopted in 1948 (1), both Enterobacteriaceae Rahn 1937 and Enterobacter Rahn became illegitimate because they were not in accord with all of the rules, which were retroactive.

In 1957, a formal proposal was made to the Judicial Commission to conserve the family name Enterobacteriaceae and to make Escherichia its type genus and Escherichia coli its type species (2). This proposal was approved in Opinion 15 of the Judicial Commission, issued in 1958 , and the family name formally became Enterobacteriaceae Rahn 1937 nom. fam. cons. (Opin. 15, Jud. Comm. 1958) (3, 9). The name Enterobacteriaceae became universally accepted and was not questioned again until 1973, when the Judicial Commission noted that although this name had not been formed according to Rule 3 of the 1958 International Code of Nomenclature of Bacteria and Viruses, it had been conserved (12). The Judicial Commission asked the Enterobacteriaceae subcommittee for 
a recommendation on this question. In 1975, The Enterobacteriaceae Subcommittee voted 12 to 2 to retain the name Enterobacteriaceae. It is important to note that the Enterobacteriaceae Subcommittee members were specifically asked to choose one of three names; 12 members voted to keep Enterobacteriaceae, 2 members voted to change the family name to "Enterobacteraceae," and none voted to change the name to Escherichiaceae. A revised version of the International Code of Nomenclature of Bacteria appeared in 1975 (11), in which Opinion 15, conserving Enterobacteriaceae, was reaffirmed.

In the minutes of their 1978 meeting (published in 1979), the members of the Judicial Commission voted to reverse Opinion 15 . The Commission "proposed to conserve the family name 'Enterobacteraceae' with the type genus Enterobacter on the grounds that this would cause less disturbance than the change to the family name Escherichiaceae with the type genus Escherichia" (8). The proposal to change the family name to "Enterobacteraceae" was formally made by Lapage (10). The Enterobacteriaceae Subcommittee voted 11 to 0 against this proposal, and the American Society for Microbiology Subcommittee on Gram-Negative Facultatively Anaerobic Fermentative Rods (ASM Subcommittee) voted 7 to 0 against it. Arguments against the proposal were published in $1980(5,6)$. In 1981 the proposal of Lapage to change the family name to "Enterobacteraceae" was rejected by the Judicial Commission (14).

Since the proposal of Goodfellow and Trüper to change the family name to Escherichiaceae was published in 1982, both the Enterobacteriaceae Subcommittee and the ASM Subcommittee have unanimously voted ( 9 to 0 and 8 to 0 , respectively) against it. These votes are not surprising since the Judicial Commission stated (see above) that Escherichiaceae would cause more disturbance than "Enterobacteraceae" (8), and both the Enterobacteriaceae Subcommittee and the ASM Subcommittee have taken a similar view in votes and in discussions.

The people who work closely with Enterobacteriaceae have consistently voted either unanimously or overwhelmingly to keep the name. The objections of the Enterobacteriaceae Subcommittee to the proposal of Escherichiaceae are given below.

Goodfellow and Trüper stated that Enterobacteriaceae is not formed according to the rules of bacteriological nomenclature and that the name is retained for "merely historical reasons" (7). When Enterobacteriaceae was formed, there was no Bacteriological Code. The name became conserved, legitimate, and in accordance with the rules of nomenclature in 1958 when Opinion
15 was adopted. Once adopted, Opinions are part of the rules of nomenclature; thus, Enterobacteriaceae is a legitimate name, not an illegitimate name as is often stated by those who wish to change it. Enterobacteriaceae is maintained because it conforms to the rules of nomenclature as specifically covered by Opinion 15 and because it is probably the most widely known and accepted family name in bacteriology. The validity of Opinion 15 and the validity of the name Enterobacteriaceae have repeatedly been reaffirmed in Judicial Commission actions and in the Bacteriological Code for 25 years. In actual practice, Escherichiaceae has been used in the literature once (7), whereas since its introduction Enterobacteriaceae has been used, by conservative estimates, more than 100,000 times (5). A name change would cause a tremendous amount of confusion for all nonexperts. It would be particularly difficult for computer programmers and those who use computer abstract searches. Every program currently in use would have to be altered to cross-reference Enterobacteriaceae and Escherichiaceae, a time-consuming and expensive task.

Those who oppose the name Enterobacteriaceae have never argued that it is confusing or misunderstood. Their arguments have been solely on the basis that Enterobacteriaceae was not formed in accordance with Rule 9 of the 1975 Bacteriological Code $(7,8,10)$. Rule 9 states: "Names of taxonomic groups (taxa) between suborder and genus are formed by the addition of the appropriate suffix to the stem of the name of the type genus" (11). Enterobacteriaceae has an extra i and does not represent the type genus, which is Escherichia. Although Enterobacteriaceae does not satisfy Rule 9 , it is totally in accordance with the rules of nomenclature because it was specifically excepted from Rule 9 by having been conserved in Opinion 15 (11) under the Bacteriological Code. This and other exceptions to the rules of nomenclature have been allowed, in accordance with many of the principles and rules of nomenclature.

General Consideration 6 of the Code allows "for emendations of rules" and "for special exceptions to the rules" (11). The conservation of Enterobacteriaceae under Rule 21b (12) in Opinion 15 is such an exception. Rule 21 b states: "If the name of a family was not made in conformity with Rule 21a but its name has been conserved, then the type genus may be fixed by an Opinion of the Judicial Commission." The following example is given: "The genus Escherichia is the type genus of the family Enterobacteriaceae (Opinion 15)." Thus, Rule 21b and Opinion 15 specifically make Enterobacteriaceae a legitimate name under the Bacteriological Code. 
Principle 1 (11) states: "The essential points in nomenclature are ... (1) aim at stability of names, (2) avoid or reject the use of names which may cause error or confusion, (3) avoid the useless creation of names." Retention of the name Enterobacteriaceae satisfies all three of these points. The use of Escherichiaceae would cause a great deal of confusion. It is a useless name, in that its only purpose is to eliminate a legitimate exception to Rule 9.

Principle 8 and Rule 28a (11) state: "Each order or taxon of a lower rank with a given circumscription, position, and rank can bear only one correct name, i.e., the earliest that is in accordance with the Rules of the Bacteriological Code." Enterobacteriaceae is the only correct name for the family, and it is in accordance with the rules of the Code. Escherichiaceae is currently, in our opinion, an illegitimate name.

Principle 9 (11) states: "The name of a taxon should not be changed without sufficient reason based either on future taxonomic study or on the necessity of giving up a nomenclature that is contrary to the rules of this Code." The proposed change to Escherichiaceae is not based on taxonomic study, and Enterobacteriaceae is in accord with the Bacteriological Code as specifically addressed in Rule $21 \mathrm{~b}$ and Opinion 15.

Rule 56b (11) states: "A conserved name (nomen conservandum) is a name which must be used instead of all earlier synonyms and homonyms. A conserved name (nomen conservan$d u m$ ) is conserved against all other names for the taxon, whether these are cited in the corresponding list of rejected names or not, so long as the taxon concerned is not united with another taxon bearing a legitimate name." This rule clearly indicates that the conserved name Enterobacteriaceae should continue to be used since this taxon has not been combined with any other taxon.

The only reason which Goodfellow and Trüper give in support of the proposed change is that Enterobacteriaceae does not conform to Rule 9 of the Bacteriological Code. However, it does not have to conform to Rule 9 , because it is specifically excepted from Rule 9 by Opinion 15 and Rule $21 \mathrm{~b}$. There is no doubt concerning the legitimacy of Enterobacteriaceae under the current Bacteriological Code. The rejection of Enterobacteriaceae and the adoption of Escherichiaceae would violate the following parts of the Bacteriological Code (see above): General Consideration 6, Principles 1,8 , and 9, Rules $21 \mathrm{~b}$, 23a, and 56b, and Opinion 15. Therefore, the proposed name Escherichiaceae is untenable from the standpoint of the rules of nomenclature.

Principle 1 of the Bacteriological Code is concerned with the stability of names and the avoidance of confusion in nomenclature. The proposal of Escherichiaceae is in conflict with Principle 1 because from a practical standpoint, the proposed name change would cause confusion and consternation. The validity of Enterobacteriaceae has repeatedly been reaffirmed by the Judicial Commission and in the Bacteriological Code. The Enterobacteriaceae Subcommittee has consistently opposed attempts to change the name Enterobacteriaceae and has voted unanimously against the Escherichiaceae proposal. Enterobacteriaceae has been universally accepted for more than 45 years. We doubt that another name would be accepted by the scientific community and used in the scientific literature.

For all of these reasons, the members of the Subcommittee on the Taxonomy of Enterobacteriaceae of the International Committee on Systematic Bacteriology unanimously recommend that the Judicial Commission reject the proposal of Goodfellow and Trüper to replace the Enterobacteriaceae with Escherichiaceae.

\section{LITERATURE CITED}

1. Buchanan, R. E., R. St. John-Brooks, and R. S. Breed (ed.). 1948. International bacteriological code of nomenclature. J. Bacteriol. 55:287-306.

2. Editorial Board, Judicial Commission. 1957. Proposal to conserve the family name Enterobacteriaceae and to designate the type genus. Int. Bull. Bacteriol. Nomencl. Taxon. 7:165-166.

3. Editorial Board of the International Committee on Bacteriological Nomenclature. 1958. Opinion 15. Conservation of the family name Enterobacteriaceae, of the name of the type genus, and designation of the type species, p. 162. In International code of nomenclature of bacteria and viruses. The Iowa State University Press, Ames.

4. Ewing, W. H., J. J. Farmer III, and D. J. Brenner. 1980. Proposal of Enterobacteriaceae fam. nov., nom. rev. to replace Enterobacteriaceae Rahn 1937, nom. fam. cons. (Opin. 15, Jud. Comm. 1958), which lost standing in nomenclature on 1 January 1980. Int. J. Syst. Bacteriol. 30:674-675.

5. Farmer, J. J., III, D. J. Brenner, and W. H. Ewing. 1980. Opposition to recent proposals which would reject the family name Enterobacteriaceae and Escherichia as its type genus. Int. J. Syst. Bacteriol. 30:660-673.

6. Farmer, J. J., III, D. J. Brenner, and W. H. Ewing. 1980 Enterobacteriaceae: judicial action has been proposed which would make it a rejected name and prevent its use in the literature. ASM News 46:275-279.

7. Goodfellow, M., and H. G. Trüper. 1982. Escherichiaceae nom. nov., a name to replace Enterobacteriaceae. Request for an Opinion. Int. J. Syst. Bacteriol. 32:383.

8. International Committee on Systematic Bacteriology Judicial Commission. 1979. Minutes of the meeting, 3 September 1978. Int. J. Syst. Bacteriol. 29:267-269.

9. Judicial Commission of the International Committee on Bacterial Nomenclature. 1958. Conservation of the family name Enterobacteriaceae, of the name of the type genus, and designation of the type species. Int. Bull. Bacteriol Nomencl. Taxon. 8:73-74

10. Lapage, S. P. 1979. Proposal of Enterobacteraceae nom nov. as a substitute for the illegitimate but conserved name Enterobacteriaceae Rahn 1937. Request for an Opinion. Int. J. Syst. Bacteriol. 29:265-266.

11. Lapage, S. P., P. H. A. Sneath, E F. Lessel, V. B. D. Skerman, H. P. R. Seeliger, and W. A Clark (ed). 1975 
International code of nomenclature of bacteria. 1975 Revision American Society for Microbiology, Washington, D.C.

12. Lessel, E. F. 1974. Judicial Commission of the International Committee on Systematic Bacteriology, minutes of meeting, 29 August 1973. Int. J. Syst. Bacteriol. 24:379380 .
13. Rahn, O. 1937. New principles for the classification of bacteria. Zentralbl. Bakteriol. Parasitenkd. Infektionskr. Hyg. Abt. 2 96:273-286.

14. Wayne, L. G. 1982 . Actions of the Judicial Commission of the International Committee on Systematic Bacteriology on requests for opinions published between July 1979 and April 1981. Int. J. Syst. Bacteriol. 32:464-465. 